\title{
Strategies of Enhancing Instructional Leadership Competence of Principals
}

\author{
Gao Yan \\ Southwest University, Chongqing, China
}

\begin{abstract}
Instructional leadership competence of principals is a unique combination of abilities that principals are required to have, in order to successfully perform duties of this particular role. Instructional leadership competence of principals includes knowledge, skills, self-concept, values, motivations, personality traits, and so on. On one hand, enhancing instructional leadership competence requires principals to insist on teaching as a core of school education, establish a new system of instructional leadership for standardization, follow teaching rules, organize teaching activities, and guide teaching activities in in-depth practice. On the other hand, principals need to continuously upgrade their literacy, understand the role of principals' instructional leadership correctly, do self-reflection, adhere to lifelong learning, and strengthen the practice of instructional leadership experience.
\end{abstract}

Keywords: instructional leadership, principal, competence, enhance

\section{Introduction}

With the advent of the era of knowledge-based economy, education in social life becomes more and more prominent. Primary and secondary school principals, as the core of leadership, their educational philosophy and work styles directly affect the development of school and future. Education concerns the future of a country. In order to achieve a new situation "educators run schools", instructional leadership competence of principals must be enhanced. Instructional leadership competence of principals is a unique combination of abilities that principals are required to have, in order to successfully perform duties of this particular role, including knowledge, skills, self-concept, values, motivations, personality traits, and so on. As the overall quality of a leader's wisdom and leadership, instructional leadership competence of principals is neither naturally occurring, nor accomplished at one stroke, but results from external teaching requirements, cultivation, training, and active practice in the process of the leadership activities.

\section{Enhancing Principals’ Instructional Leadership Competence Based on School Teaching Job}

Principal leadership should adhere to the teaching-oriented idea. A correct understanding of the role of teaching in all work of the school is the premise to improve instructional leadership competence of principals. To insist on the "teaching-oriented" idea, principals can comprehend it from three aspects.

\section{Adhering to Teaching is Dominated by the Fundamental Task of the School}

School is an organization dedicated to carry out educational activities, and its mission is to cultivate talents.

Gao Yan, Ph.D. candidate, associate researcher, Faculty of Education, Southwest University. 
The work to cultivate people needs a variety of school activities together, such as teaching, moral activities, and management activities, which are very important for improving the quality of school education. However, in these activities, the school's core activity and key job is teaching, and other work must commence around teaching and serve it. Teaching is one of the most frequent work in the maximum amount. Adhering to the teaching-oriented idea directly influences and restricts the other work of the school.

\section{Adhering to Teaching is the Need of Achieving Educational Training Goals}

Achieving core educational goals mainly relies on the school's teaching activity which is the most basic way for the school to implement the education policy. Only through teaching can teachers impart knowledge to students and can they develop students' intelligence; only through teaching can teachers cultivate students' moral character and behavior; only through teaching can students' physical and psychological quality be developed; and only through teaching can teachers implement the "five ways of life" (Tang, 2009) and cultivate all-round development and complete person.

\section{Adhering to Teaching Is Consistent With the Main Requirements of "National Medium- and Long- Term Educational Reform and Development Program (2010-2020)”}

The National Medium- and Long- Term Educational Reform and Development Program (2010-2020) stressed, when measures of education reform are taken, principals should be based on the need of improving teaching quality; they should establish teaching-oriented school-running concept and quality view that adapt economic and social development; guide society, family, school, teachers, and students to form a correct awareness of teaching quality; adhere to combining theory and practice, teaching and life; and make students focus on independent sense of learning, practice, exploration capability, and pioneering spirit. Popularization of compulsory education meets the basic needs of school-age children. The emphasis of basic education gradually turns from the focus that "Everyone is able to learn in school" to the one that "Everyone is able to learn quite well in school”, and turns from scale expansion to improvement of the quality, and in order to improve the quality of education, teaching can be paid more attention to. Therefore, principals should focus on teaching. If a principal does not pay attention to teaching, it will be as incomprehensible as the situation that a factory director does not concern the production.

How can principals adhere to teaching? First, principals should keep in mind that teaching is the fundamental way to implement the education policy and promote the development of education, which is the most important way to cultivate talents. They cannot treat teaching as purely intellectual education. Second, in the process of leading, principals should spend more time and energy in making efforts to guide teaching and studying, and they should overcome formalism and cumbersome philosophy. "Every reform of education and teaching, only in the classroom, can be implemented to succeed; every teaching achievement must rely on classroom teaching” (Wang, 2012, p. 152). Third, about the specific method, principals should ensure the successful completion of the task of teaching, through their own management art, so that various work can actively and methodically serve the teaching work, and achieve the purpose of educating people.

\section{Achieving Standardization of Teaching Leadership by Establishing a New System}

\section{Responsibilities of Teaching Staff Must Be Made Clear}

According to the document issued by superiors and the actual condition, principals with school management, teachers, and representatives should work out their duties to prompt them to fulfill their duties as required. 


\section{Principals Should Establish Teaching Regulations}

During the whole process of teaching, every aspect should be proposed the scope of work and quality requirements. Specifically speaking, the first is the regular teaching program. Drawing up teaching plans is important to ensure the full completion of the teaching task, and it includes the design of the school teaching program, working plan of teaching and research group, and working program of teaching. Different levels of planning propose different goals, tasks, and requirements. The second is the administration work routine. This is an important aspect which establishes a normal teaching order and ensures teaching work carry on smoothly. General administration work includes grouping of classes, making curriculum, timetable, activities table, and the school calendar, check the teaching and the organization of teaching and research, observing school teaching activities, arranging exams, and summarizing teaching. The third is the conventional teaching system. Establishment of perfect teaching management rules and regulations is essential to ensure the implementation of the teaching management. Teaching system includes a regular meeting system of the principal's office and dean's office; work regulations of teaching and research group; conventional teaching of various subjects; the routine of students' learning; rules of library, laboratories, and other special classrooms; and assessment standards and incentives on advanced group of teachers and students. The fourth is the teaching and research routine. Teaching research is an effective way to improve the professional level of teachers and quality of classroom teaching. Teaching research includes two aspects. First, teaching research of the school, named school-based teaching research in which activities mainly include conveying specific policies and directives, learning educational theory, the organization of symposia, exchanging experiences, and carrying out activities, such as teaching assessment and so on. Second, activities of teaching and research group and grade lesson planning group are similar to those of the former. The fifth is teaching quality management, which is the core of instructional leadership, and principals should grasp the management in the whole process of the formation of the quality. It mainly includes three aspects: (a) requirements for teachers preparing lessons, classes, layout and correcting homework, tutoring, and performance assessment; (b) basic requirements of the students' preparation, lectures, review, assignments, and exams; and (c) to do a good summary job of teaching quality management, which requires both semester or academic year summary and a stage summary, both a comprehensive summary and a thematic summary, both the school summary and a summary of teaching and research group, and both leaders' summary and teachers and students' summary.

\section{Governing and Organizing Teaching in Accordance With the Teaching Law}

Classroom teaching, as a basic form of school education, has its own laws. Teaching law is the internal, intrinsic, and necessary relation and development trend constituting various factors of the teaching process. Principal leadership in the teaching process should actively guide teachers to perform teaching by the teaching law.

\section{Comprehending and Mastering the Mutual Promotion Between Indirect Experience and Direct Experience}

As a special process of cognition and affection, teaching can help students grasp the known human cognition achievement quickly and effectively. The teaching process based on students' direct experience, not denying relevant direct experience, requires students comprehend book knowledge firstly, and then master and consolidate it by independent thinking. The profound and successful comprehension of knowledge is 
accompanied by students' rich direct experience. Nowadays, most teachers perform that law in classroom teaching. However, some teachers have the tendency of cognizing partially, only instilling abstract book knowledge to students' mind, conservatively repeating what the book says, denying integrating book knowledge with society, and fulfilling practice. Hence, principals should urgently instruct teachers to overcome and correct that kind of tendency.

\section{Integrating the Ability of Mastering Knowledge With Intelligence Development}

There is an interpersonal and complementary relationship between knowledge teaching and intelligence development. Mastering knowledge is the basis of developing intelligence, and vice versa. The instruction of principals in establishing teachers' sense of comprehensive objectives benefits teachers' performing that law in teaching activities. If teachers just focus on accomplishing knowledge teaching, they are not qualified teachers. However, if teachers accomplish knowledge teaching and develop intelligence at the same time, they would be comparatively qualified teachers. If teachers add some factors, such as moral education, innovation sense, etc. to the above two missions, they would be qualified teachers.

\section{Grasping the Law of Integrating Teaching With Morale Education}

In the teaching process, teachers impart knowledge to students, regardless of social scientific knowledge or natural sciences, based on fluent ideological and moral education factors. In order to apply that law to guide teaching successfully, firstly, it is necessary for principals to properly instruct teachers in dealing with the relationship between teaching and educating, thus promoting teachers to teach with right ideology and morality ideas. Secondly, principals must pay attention to looking for the ideological and moral factors, not emphasizing politics and highlighting morality. Thirdly, principals should influence teachers and students with their leadership style as well as verbal instruction.

\section{Mastering the Rules of Coordination in Teachers' Leading Role and Students' Subject Role}

Teachers and students are key factors which influence the quality of teaching. Teaching is for students' learning and learning is under the guidance of teachers. Only both of them promote each other can the teaching process be optimized. Implementing this law in the teaching process, principals should pay attention to mobilizing the enthusiasm of both teachers and students, so that both can mutually adapt to each other. Teachers should pay attention to the art of teaching, give students ample opportunities to show themselves, and never be arrogant and perform a one-man show. Teachers should do whatever they can do well and strive to achieve perfection.

\section{Guiding Teaching Activities by Further Practicing}

A principal, as a member of the faculty, to promote the quality of teaching in a large area and improve instructional leadership competence, is required to go to the first-line teaching, enter the classroom, and go to the middle of the teachers and students to conduct research on the issues and make decisions to guide work. First, principals must actively participate in the formulation of the teaching plan each semester. Teaching plan is an important role in guiding as a program of action in the process of teaching. Principals should formulate teaching plans of each semester as the school's top priority, so that plans can be operational and detectable. Second, principals must adhere to part-time teaching and classroom observation. The purpose of principals' teaching is not to replace teachers or make up for lack of teaching staff, but to set an example, lead teachers do a good job in teaching, and explore ways to reform and development. Meanwhile, after sharing joy and sorrow 
with teachers, they will have a common language. Understanding the actual situation, principals can facilitate the access of discourse right and the guiding force. Third, principals should organize teachers to take part in teaching and research activities. Teaching research is the foundation of improving the operational capacity of teaching, "the source of power" for the sustainable development of school. In order to teach well, not only should they pay attention to the practice, but also should do some research from the combination of theory and practice. It is impossible to improve the quality of teaching only through teaching. In teaching and research activities, principals should not only listen, look, and talk about something. What is more important for teachers is that through communication and discussion of teachers' teaching content and teaching methods in teaching and research activities, individual differences among teachers can be reduced and wisdom of individual teachers can be concentrated, so that eventually they improve the realization of the common purpose and improve the effectiveness of teaching and research activities. What is more, improving service levels to their principals is also very helpful. Fourth, principals should personally preside over and participate in one or two teaching reform projects, to know the rest from what has been known. Principals' leadership should not be limited to grasp the regular teaching, but also attach to the teaching reform, because only in the teaching of reforms can various disadvantages be overcome.

\section{Enhancing Instructional Leadership Competence According to Principals' Professionalism}

The primary and secondary school principal is not only the object in the promotion of instructional leadership competence, but also the main subject in it. As the main subject of development, the principal needs to continue to make efforts in the following areas.

\section{A Correct Understanding of the Role of Instructional Leadership as a Principal}

In the process of playing their specific career roles, school principals form and improve their instructional leadership competence. Therefore, to some extent, whether a principal can improve competence depends largely on the strength of the consciousness of the role and the appropriate role definition. If the principal has a strong sense of character, he/she will actively act as required, and consciously apply learned professional knowledge to guide leadership action. His/her role's obligations, rights, specification, emotion, and attitude will be internalized as the role concept which dominates action. If the principal has the right role definition, he/she will require himself/herself according to duty standard, and consciously enhance the leadership competence of teaching in the role practice. On the contrary, if the principal has no strong sense of professional role and cannot give himself/herself the right role definition, his/her behaviors may not adapt to professional roles and even be contrary to professional roles. Therefore, to promote instructional leadership competence, principals must carry on the correct role cognition first. Principal role cognition means understanding of one's own rights and obligations as a principal. Modern principals’ roles are multiple and complex.

Nowadays, principals are very busy for different kinds of things. For example, school is in the renovation and expansion; teachers should be prized with some title; and students want further study to develop personality. They must cope with the order given and adjust internal fighting. They have to participate many meetings and receive a steady stream of visitors. Besides, they have to participate in numerous competitions and accept the various checking. They treat the visit of executives as festivals, and when visited by foreign dignitaries, they will be flattered. They also worry about some unimportant things for long time. For example, a student break head to trouble a few days, or several students fail in the exam. They can only find time to ask the condition of teaching and learning. (Cheng, 2010, p. 1) 
Principals thereby produce "omniscient" consciousness, and eventually emerge the phenomenon of dislocation, offside, and absence, namely, principals do not play the right role well, but spend a lot of time and energy on the role of the principal it should not be.

How should principals play the correct role of cognition? On December 24, 2012, the Ministry of Education of China (2012) issued Compulsory School Principal Professional Standards (Trial). It clearly mentioned that in the field of educational leadership, professional duties of school principals include the following three aspects:

1. Professional understanding and awareness: School principals should adhere to all students, teach students in accordance with their aptitude, comprehensively improve the quality of teaching, respect for the law of education, focus on students' sense of responsibility, innovative spirit, and practical ability, respect for teachers' teaching experience and wisdom, and actively promote the teaching reform and innovation;

2. Professional knowledge and methods: School principals should master students' training objectives and curriculum standards in different stages of development; understand curriculum development and implementation, relevant knowledge of curriculum evaluation, and policy of teaching materials, as well as the experience of domestic and foreign curriculum reform; and master the classroom teaching, general principles and methods of the application of educational information technology;

3. Professional competence and behavior: School principals should effectively plan the overall national, local, and school level courses, to ensure the implementation of national and local curricula, promote the development and implementation of school-based curriculum, and provide students with rich variety of teaching resources. They should also earnestly implement compulsory education curriculum standard, protect students from the heavy burden, not arbitrarily increase the difficulty of the class and not occupy the lessons of sports, music, art, and so on. Besides, they should ensure that students can do sports activities one hour each day, establish a system of attending and evaluating lectures, attend more lectures than asked by the local educational administrative departments, and give some suggestions to lecturers. They should actively organize research activities and carry out teaching reform. Teaching evaluation system also should be established to promote students' comprehensive development which cannot be judged by test scores and graduation rates.

\section{Being Good at Self-reflection}

Social development and change make the leading problems in teaching be confronted with increasing diversity, integration, and unpredictability. In order to be able to manage those challenges and satisfy the needs of educational reform, principals must know how to update the concept of educational leadership, correct the goals of educational leadership, construct teaching value system, complement teaching knowledge and skills, control teaching methods, and so on. However, all of these are determined by the willingness and fondness of principals to reflect. The so-called reflection refers to the ability to conduct self-criticism behaviors and context independently of themselves. The purpose of exerting this capability is to promote thinking pattern for professional knowledge rather than habitual, traditional, and impulsive actions based on convincing. The process of reflection, in essence, is to reflect on their own thoughts and behaviors so that these things can be improved continuously (Valli, 1992, p. 100).

Reflections come from the pursuit and role expectations of the subjects. If an individual feels satisfied for achieving a role expectation, then he/she might not have a strong sense of reflection. Therefore, principals should have the courage to face reality and admit mistakes and negligence. Meanwhile, they must have a 
certain ability to reflect, decompose, examine, and analyze according to the goal through the leading behaviors, processes, and effects of themselves. Moreover, they can explore instructional laws and improve leading methods and leading behaviors in teaching according to communication and cooperation between the teachers and students, so as to improve the leadership effectiveness and teaching quality.

\section{Insisting on Lifelong Learning}

Learning is the only way and method to constantly improve a person. Learning is not only necessary for being competent as a principal, but for the principal to set a good example for teachers and students. "A principal's time is quite limited. It really needs to make a firm decision to squeeze time from busy schedule to learn new things. Then, it might have considerable influence on his/her colleagues” (Lin, 2002, p. 85).

Principals who insist on learning are willing to accept new knowledge and ideas. Once, they integrate their inherent systems of knowledge and ways of thinking into their own unique insights on teaching and research, they can play a better role in studying and leading teaching and improve their leading ability in teaching, which ultimately results in teaching reform. Insisting on lifelong learning should consist of learning from books and practice, learning from experts and colleagues, and even learning from students and parents. Through the exchange of ideas and mutual discussion, people's horizons can be broadened and thoughts can be inspired in the process of brainstorming and adopting others' strong points while overcoming their weak points. For instance, the theory of school management, leadership, teaching, and philosophy may as well be learned and mastered. Moreover, when being involved in a dynamic learning atmosphere and conducting surveys and research in different departments, disciplines, classes, schools of good relation, teachers, and students, more knowledge can be obtained to increase abilities.

\section{Strengthening the Self-Cultivation of Instructional Leadership}

\section{Strengthening the Academic Self-cultivation}

Cyxomjnhcknn (2009) said, "If you want to be a good president, you first have to become a good teacher, a good educational expert and educator". As "the teacher of the teachers”, a principal's professional knowledge and academic training impact on teachers is immeasurable. A principal with professional knowledge has a greater influence on the form of power than the principal without the expertise, and thus, he/she attains trust of others (Wang, 1993, p. 106).

Principals should continuously learn, absorb, and keep in touch with new teaching theory, and actively explore new teaching methods to enrich their teaching knowledge and education awareness, and strive to become experts who are in consistent with social development in education. Only in this way will they have the right to say something in the leadership of teaching practice in order to help and support teachers to improve teaching methods to enhance the teaching ability. Imagining a principal who neither give nor attend lectures, what could he/she use to guide teachers who teach in classrooms, and what can he/she use to study, manage, and lead teaching.

\section{Improving Teaching Training}

The principal means not only a job or an occupation, but also a profession. The cultivation of teaching leadership does not refer to academic attainments or the improvement of teaching leadership, but the attainments of both academic and teaching leadership. Seen from the perspective of human science, principals should not only be the key figures of mastering and commanding the overall situation, but also the ones who 
are skilled at fighting and mastering the martial art. If principals focus only on improving the academic accomplishments, they might be able to persuade people, but not necessarily be able to unite the subordinates. Similarly, if principals focus only on improving teaching leadership skills, they may make the staff act as what they said, but may not necessarily make them convincing. Therefore, to improve the effectiveness of teaching leadership, principals should also improve the professional level and teaching leadership skills.

\section{Strengthening Morality}

Principals, who are models, are the teachers of the division. School principals have a lofty and high status in the hearts of the members in the school. It can also be predicted that the requirements of a principal are very high, especially in moral aspects. This requires that principal leaders in the teaching process must strengthen the teaching morality and self-improvement. They must have a sense of justice and dedication. They must have a sense of considering and worrying about something before teachers and students, feeling relieved after the happiness of teachers and students, and "holding a heart without asking for anything in return" (Tao, 2005); be able to make themselves a model; have high spirits; care about others first; and dedicate selflessly in the teaching activities of the school.

\section{Strengthening Psychological Training}

In the development of school teaching, various difficulties, frustration, and even failure will inevitably occur, which would have a great impact on principals' mentality. Thus, principals must strengthen their psychological training to form strong self-adjustment capabilities, including resilience, strength, and self-control, and develop such psychological qualities as a stable optimism, a strong will, and so on. When carrying out the teaching leadership, no matter what occurs, principals should face it enthusiastically with a positive attitude. They should win without pride, lose with grace, and lead school staff with a strong will and resolute courage to struggle for pre-school teaching objectives. In addition, principals' mental health is also presented by their willingness to be a good judge of talents, to be "green leaves", and to be the unsung heroes, and to provide opportunities and platforms for staff development. This requires principals to overcome the selfish mentality of self-interest, to tolerate both people's merits and shortages, and both accept talents and endure those inferior ones.

\section{Strengthening the Practical Experience of the Teaching Leadership}

Leadership is a social practice, which determines that the principal leadership is pointed to teaching practice, rooted in practice, and serve practice. Therefore, to enhance instructional leadership competence, principals not only have to learn teaching theory and leadership knowledge, but also have to practice in real situations.

“Trained personnel will mature only if we give them free rein” (Deng, 1993, p. 17). New teaching ideas and managing experiences can only be tested in specific schools to make sure whether they work or not. Similarly, for principals, they can do practical exercise by different school attachment or job rotation. Different school attachment means that the principal holds a post in other schools, in particular those with relatively large differences in various aspects from his/her own schools. This will lead him/her to achieve different teaching leadership objectives in different educational contexts which aim at different objects, thus enriching his/her experience in teaching leadership, developing his/her teaching leadership skills, and enhancing his/her teaching leadership level. Job rotation refers to let principals take turns working in different management and non-management positions in schools and related departments. For example, the work of a teacher in charge of 
a class is very hard, but the principal may have to try personally for some time to know how hard it is. In addition, moral education is difficult to carry out, but it is not clear what exactly the problem is. Thus, principals can personally experience for looking for the crux. Job rotation can enrich principals' technical knowledge, management skills, and job experience, let them personally experience and understand the whole picture of school education organization, master a variety of teaching situations, and observe the joy of teaching staff at all levels of schools to get the first-hand information for their own decision-making and leadership. Moreover, this method can cultivate their spirit of collaboration and system concepts so that they can consciously start from the perspective of the system and deal well with the relationship between part and whole when solving specific problems in school teaching. In addition, job rotation can lead a close relationship between the principal and the school staff which is conducive to lay a solid foundation for effectively carrying out their teaching leadership.

\section{Conclusion}

In conclusion, primary and secondary school principals, as the core of leadership, need to promote instructional leadership competence, which brooks no delay. In order to promote instructional leadership competence of principals, this paper mainly tries to solve it from two aspects, which are based on school teaching job and principals' professionalism. In each aspect, the author has put forward some important strategies which can be applied in the process of enhancing instructional leadership competence. Enhancing instructional leadership competence is not an easy job. It demands continuous and painstaking efforts by principals. Enhancing instructional leadership competence calls for more strategies which are emerging or will be emerging, and it calls for combining theory with daily practice. Only in this way can we look forward to further development in this field.

\section{References}

Cheng, G. S. (2010). Truth of school. Shanghai: Eastern China Normal University.

Cyxomjnhcknn, B. A. (2009). Talks with young teachers. Peking: Educational Science Publish House.

Deng, X. P. (1993). Selected works of Deng Xiaoping (Vol. III). Peking: People's Publishing House.

Lin, M. D. (2002). The study of principals: Job analysis and orientation of role research. Taipei: Wu-Nan Book Publishers, Ltd. Ministry of Education of China. (2012). Compulsory principal professional standards (Trail). Retrieved from http://www.moe.ed u.cn/publicfiles/business/htmlfiles/moe/s6197/201212/146003.html

Tang, G. Q. (2009). Freedom and harmony: Cai Yuanpei’s five ways of life. Sichuan: Bashu Publishing House.

Tao, X. Z. (2005). The complete works of Tao Xingzhi (Vol. III). Sichuan: Sichuan Education Publishing House.

Valli, L. (1992). Reflective teacher education: Cases and critiques. Albany, N.Y.: SUNY Press.

Wang, T. J. (1993). The study of principals. Nanjing: Phoenix Educational Publishing, Ltd..

Wang, T. J. (2010). Practice of principal leadership. Shanghai: Eastern China Normal University. 